\title{
ETANERCEPT IN CHRONIC PLAQUE PSORIASIS
}

\section{Ramasamy P.P*, Bharathi .S, Swarnalakshimi .S, Madhavan.R. Department of Dermatology, Coimbatore Medical College Hospital. Coimbtore, Tamilnadu.}

\begin{abstract}
Psoriasis is a chronic inflammatory disease with frequent relapses and remissions. The introduction of biologicas increased the remission periods, decreases relapse and hence improve the quality of life.

Method: The study includes 17 adult patients of chronic plaque psoriasis, who received etanercept subcutaneously at a dosage of $50 \mathrm{mg}$ once weekly for 24 weeks, followed by 6 months follow up.

Results: At the end of 12 weeks 8 patients (47.05\%) achieved more than $75 \%$ reduction of PASI and at the end of 24 weeks 9 patients(52.94\%) achieved more than $75 \%$ reduction of PASI.

Conclusion: Our study shows that etanercept has good efficacy without any significant side effects and it should be considered in patients with moderate to severe chronic plaque psoriasis not responding to other conventional modes of therapy.
\end{abstract}

\section{INTRODUCTION}

Psoriasis is a chronic inflammatory skin condition affecting approximately $2 \%$ of the general population. ${ }^{(1,2)}$ Even though it has several clinical variants, chronic plaque type is the commonest that presents with silvery white scales on an erythematous base. Some patients may have associated joint involvement. The pathogenesis of psoriasis is complex it includes both innate and adaptive immune systems. Cytokines Th1 and Th17 cells have been incriminated in the pathogenesis of psoriasis. ${ }^{(3)}$ These cytokines secrete TNF- $\alpha$ and IFN $-\alpha$ that leads to vasodilatation, leukocyte migration and keratinocyte activation. This leads to activation of dendritic cells that creates a repeated cycle of inflammation.

Biologics are the agents that targets genetic or immune mediator of pathophysiological process.. Among the biologics Infliximab, Etanercept, and Adalimumab targets TNF- $\alpha$. Eternacept is a human fusion protein of the TNF receptor to Fc portion of IgG which binds to TNF $-\alpha$ to neutralize its effects. Various international studies have showed eternacept has good efficacy in chronic plaque type of psoriasis. With this background we conducted a study on efficacy of eternacept in chronic plaque psoriasis.

*Corresponding author:

Email: ramasamypp@yahoo.com

http://dx.doi.org/10.20530/IJTA $31 \quad 18-21$

ISSN 2320-138X @ 2016
Table 1: Baseline PASI Score

\begin{tabular}{ccc}
\hline NO: & AGE/SEX & $\begin{array}{c}\text { BASELINE } \\
\text { PASI }\end{array}$ \\
\hline $\mathbf{1}$ & $32 / \mathrm{F}$ & 25 \\
$\mathbf{2}$ & $29 / \mathrm{M}$ & 20 \\
$\mathbf{3}$ & $68 / \mathrm{M}$ & 30 \\
$\mathbf{4}$ & $50 / \mathrm{M}$ & 15 \\
$\mathbf{5}$ & $40 / \mathrm{F}$ & 23 \\
$\mathbf{6}$ & $41 / \mathrm{M}$ & 17 \\
$\mathbf{7}$ & $47 / \mathrm{M}$ & 30 \\
$\mathbf{8}$ & $34 / \mathrm{F}$ & 29 \\
$\mathbf{9}$ & $55 / \mathrm{F}$ & 28 \\
$\mathbf{1 0}$ & $50 / \mathrm{M}$ & 15 \\
$\mathbf{1 1}$ & $57 / \mathrm{M}$ & 12.2 \\
$\mathbf{1 2}$ & $42 / \mathrm{M}$ & 26.2 \\
$\mathbf{1 3}$ & $32 / \mathrm{M}$ & 14.5 \\
$\mathbf{1 4}$ & $47 / \mathrm{M}$ & 23.7 \\
$\mathbf{1 5}$ & $64 / \mathrm{M}$ & 15.2 \\
$\mathbf{1 6}$ & $23 / \mathrm{M}$ & 27 \\
$\mathbf{1 7}$ & $38 / \mathrm{F}$ & 30 \\
\hline & &
\end{tabular}




\section{METHODS}

Study was conducted in Dermatology department at Coimbatore Medical College from September 2011-August 2012 which constitutes 6 months of therapy and 6 months of follow up. Patients were selected based on the following inclusion criteria:a)Chronic plaque psoriasis, b) more than 18years of age, c)PASI 10 or more than 10.The exclusion criteria includes a)Paients with active infections like Tuberculosis, HIV, Hepatitis B and C, b) Patients on phototherapy, and c)Pregnant women \& children.

Seventeen patients were selected for the study based on inclusion and exclusion criteria. They were admitted in the skin ward .All the patients underwent blood investigations which included complete hemogram, liver function test, renal function test, urine routine and $x$ ray chest to rule out pulmonary tuberculosis.

Baseline PASI was done for all the patients(Table 1)( by taking into account erythema, induration and scaling, and body surface area). Patients were given subcutaneous injection of etanercept50 mg once in a week for a period of 24 weeks. No other topical or systemic drugs for psoriasis were added during the study period. Essential investigations were done once in a month for the next 6 months.PASI score was done at the end of 12 weeks and 24 weeks to assess the treatment response. Patients were then followed up for the next six months.

\section{Stastical analysis}

Mean values of PASI score was compared by using paired T TEST. The Stastical Package used was SPSS Version 19.0

\section{RESULTS}

Out of 17 patients 12 were male and 5 were female (Table 2). Two patients were in the age

Table 2: Gender Percentage

\begin{tabular}{lcc}
\hline Gender & Number & Percentage \\
\hline Male & 12 & 70.6 \\
Female & 5 & 29.4 \\
Total & 17 & 100 \\
\hline
\end{tabular}

group 18 -30yrs, nine were in the age group $30 \mathrm{yrs}$ $49 \mathrm{yrs}$ and four were in the age group 51 to $70 \mathrm{yrs}$. (Table 3). One female lost follow up and one male developed erythroderma. Fifteen patients out of 17 were followed up for the next 6 months .Psoriasis
Table 3: Age Percentage

\begin{tabular}{lll}
\hline Age group & Number & Percentage \\
\hline $18-29$ & 2 & 11.8 \\
$30-39$ & 4 & 23.5 \\
$40-49$ & 5 & 29.4 \\
$50-59$ & 4 & 23.5 \\
$>59$ & 2 & 11.8 \\
Total & 17 & 100 \\
\hline
\end{tabular}

Table 4:PASI score at the end of 12 weeks and 24 weeks

\begin{tabular}{|c|c|c|c|}
\hline NO: & $\begin{array}{l}\text { BASE- } \\
\text { LINE } \\
\text { PASI }\end{array}$ & $\begin{array}{c}\text { PASI } \\
12 \text { WEEKS }\end{array}$ & $\begin{array}{c}\text { PASI } \\
24 \\
\text { WEEKS }\end{array}$ \\
\hline 1 & 25 & 13 & 8 \\
\hline 2 & 20 & 9 & 5 \\
\hline 3 & 30 & 7.5 & 3 \\
\hline 4 & 15 & 3 & 2 \\
\hline 5 & 23 & Lost follow up & \\
\hline 6 & 17 & 6 & 2 \\
\hline 7 & 30 & 12 & 7 \\
\hline 8 & 29 & 17 & 12 \\
\hline 9 & 28 & 7 & 4.8 \\
\hline 10 & 15 & 7.5 & 3 \\
\hline 11 & 12.2 & $\begin{array}{c}\text { Developed } \\
\text { erythroderma }\end{array}$ & \\
\hline 12 & 26.2 & 13 & 6.5 \\
\hline 13 & 14.5 & 7.2 & 3.2 \\
\hline 14 & 23.7 & 11.8 & 4.8 \\
\hline 15 & 15.2 & 9.2 & 3.7 \\
\hline 16 & 27 & 10 & 4 \\
\hline 17 & 30 & 10 & 7 \\
\hline
\end{tabular}

recurred in two patients in the $5^{\text {th }}$ and $6^{\text {th }}$ month of follow up,

Mean baseline PASI was 23.04 and it was 9.55 at 12 weeks and 5.07 at the end of 24 weeks (Table 4). 
Table 5:Reduction of PASI at the end of 12 weeks and 24 weeks

\begin{tabular}{cccccc}
\hline No & $\begin{array}{c}\text { Baseline } \\
\text { pasi }\end{array}$ & Pasi 12 weeks & $\begin{array}{c}\text { Reuction of pasi in } \\
\text { percentage }\end{array}$ & Pasi 24 weeks & Reduction of pasi \\
\hline 1 & 25 & 13 & 48 & 8 & 68 \\
2 & 34 & 7 & 79 & 5 & 85 \\
3 & 30 & 7.5 & 75 & 3 & 90 \\
4 & 15 & 3 & 80 & 2 & 87 \\
5 & 23 & & & LOST FOLLOW UP & 83 \\
6 & 30 & 7 & 76 & 5 & 90 \\
7 & 40 & 9 & 77 & 4 & 58 \\
8 & 29 & 17 & 41 & 12 & 83 \\
9 & 28 & 7 & 75 & 4.8 & 73 \\
10 & 15 & 7.5 & 50 & 4 & 83 \\
11 & 12.2 & & DEVELOPED ERYTHRODERMA & 72 \\
12 & 39 & 9 & 77 & 6.5 & 70 \\
13 & 14.5 & 7.2 & 50 & 4 & 89 \\
14 & 23.7 & 11.8 & 50 & 7 & 74 \\
15 & 36.2 & 10 & 75 & 3.7 & 83 \\
16 & 27 & 10 & 63 & 7 & 5 \\
17 & 30 & & 66.67 & 5 & \\
\hline
\end{tabular}

The $p$ value between baseline PASI and PASI at 24 weeks was 0.0001 which was stasticaly significant.

At the end of 12 weeks 8 patients (47.05\%) achieved more than $75 \%$ reduction of PASI and at the end of 24 weeks 9 patients(52.94\%) achieved more than $75 \%$ reduction of PASI. All the above nine patients showed reduction of PASI from $80-90$ \%(Table 5) (Figure 1,2).

\section{DISCUSSION}

Etarnacept is one of the biological used in psoriasi: Before It is a FD
chronic afs and $F$ After $12 w k s$; for mechanism of action is by direct binding to TNF molecule in the blood and tissue and there by

Figure 1: Before and after treatment at the end of 12 weeks
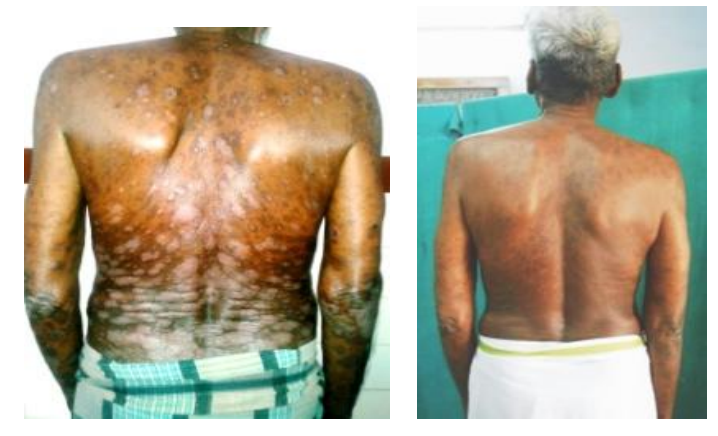

prevents its activity. Etarnacept is given as a subcutaneous injections (thighs, upper arm, abdomen) in the dose of 50mg twice weekly for the first twelve weeks and then once weekly. Mild to moderate redness, swelling, itching and pain are the common injection site reactions.

Leonardi CL et al used etarnacept 50mg twice per week and reported PASI 75 response in $49 \% \mathrm{f}$ patients aftor 10 weeks ${ }^{(4)}$. A...... etarnace Before ice per wi After 24wks $\%$ of patient achieved PASI 75 at the end ot $1 \angle$ weeks $^{(5)}$. The Pristine trial reported $78 \%$ PASI 75 by 24 weeks (6). Our study showed $53 \%$ of PASI reduction $75 \%$ at

Figure 2: Before and after treatment at the end of 24 weeks

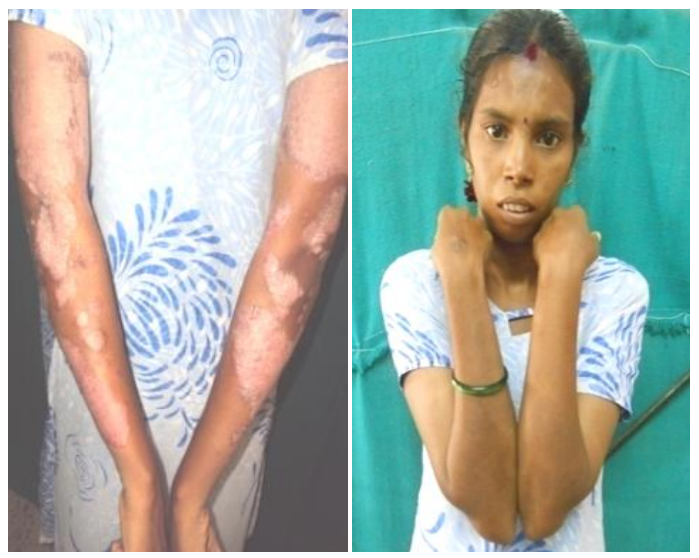


International Journal of Therapeutic Applications, Volume 31, 2016, 18-21

Stastical analysis

\begin{tabular}{|c|c|c|c|c|c|c|}
\hline & Mean & S.D. & SEM & \multicolumn{2}{|c|}{ t value } & P value \\
\hline Baseline PASI & 23.04 & 6.2 & 1.6 & \multirow{2}{*}{\multicolumn{2}{|c|}{10.241}} & \multirow{2}{*}{0.0001} \\
\hline \multirow[t]{2}{*}{ PASI 12 weeks } & 9.55 & 3.5 & 0.9 & & & \\
\hline & Mean & S.D. & SEM & \multicolumn{2}{|c|}{ t value } & $P$ value \\
\hline Baseline PASI & 23.04 & 6.2 & 1.6 & \multirow{2}{*}{\multicolumn{2}{|c|}{13.826}} & \multirow{2}{*}{0.0001} \\
\hline \multirow[t]{2}{*}{ PASI 24 weeks } & 5.07 & 2.7 & 0.7 & & & \\
\hline & Mean & S.D. & SEM & \multicolumn{2}{|c|}{ t value } & $P$ value \\
\hline PASI 12 weeks & 9.55 & 3.5 & 0.9 & \multirow{2}{*}{\multicolumn{2}{|c|}{11.008}} & \multirow{2}{*}{0.0001} \\
\hline PASI 24 weeks & 5.07 & 2.7 & 0.7 & & & \\
\hline \multicolumn{7}{|c|}{ ANOVA } \\
\hline \multicolumn{7}{|c|}{ VAR00006 } \\
\hline & Sum of Squares & df & Mean Square & $\mathbf{F}$ & Sig. & \\
\hline Between Groups & 2625.906 & 2 & 1312.953 & 67.901 & .000 & \\
\hline Within Groups & 812.127 & 42 & 19.336 & & & \\
\hline Total & 3438.032 & 44 & & & & \\
\hline
\end{tabular}

the end 24 weeks which is comparable with the above study.

The advantages of etarnecept are its dosing schedule and less common side effects. The limitation of its usage is the cost factor.

Since our study had very small sample size and the Patients were followed up for only 6 months, we were not able to calculate the exact remission period.

\section{ACKNOWLEDGMENTS}

We thank all the study participants for their cooperations and also we thank our Dean for permitting us to conduct this study.

\section{REFERENCES}

1. Raychaudhuri SP, Gross J. A Comparative Study of Pediatric Onset Psoriasis with Adult Onset Psoriasis. Pediatr Dermatol. 2000 May;17(3):174-8. http://dx.doi.org/10.1046/j.1525-1470.2000.01746.x

2. Raychaudhuri S, Farber E. The prevalence of psoriasis in the world. J Eur Acad Dermatol Venerol. 2001 Jan;15(1):16-7. http://dx.doi.org/10.1046/j.14683083.2001.00192.x

3. Zaba LC, Cardinale I, Gilleaudeau P, Sullivan-Whalen $M$, Suarez-Farinas $M$, Fuentes-Duculan J, et al. Amelioration of epidermal hyperplasia by TNF inhibition is associated with reduced Th17 responses. Journal of Experimental Medicine. 2007 Dec 17;204(13):3183-94.

http://dx.doi.org/10.1084/jem.20071094.
4. Leonardi CL, Powers JL, Matheson RT, Goffe BS, Zitnik $R$, Wang $A$, et al. Etanercept as Monotherapy in Patients with Psoriasis. N Engl J Med. 2003 Nov 20;349(21):2014-22.

http://dx.doi.org/10.1056/nejmoa030409

5. Gottlieb AB, Matheson RT, Lowe N, Krueger GG, Kang S, Goffe BS, Gaspari AA, Ling M, Weinstein GD, Nayak A, Gordon KB, Zitnik R. A randomized trial of etanercept as monotherapy for psoriasis. Arch Dermatol. 2003 Dec;139(12):1627-32; discussion 1632. PubMed PMID: 14676082.

6. Thaçi D, Galimberti R, Amaya-Guerra M, Rosenbach T, Robertson $D$, Pedersen $R$, et al. Improvement in aspects of sleep with etanercept and optional adjunctive topical therapy in patients with moderateto-severe psoriasis: results from the PRISTINE trial. J Eur Acad Dermatol Venereol. 2013 Jul 15;28(7):9006. http://dx.doi.org/10.1111/jdv.12207. 